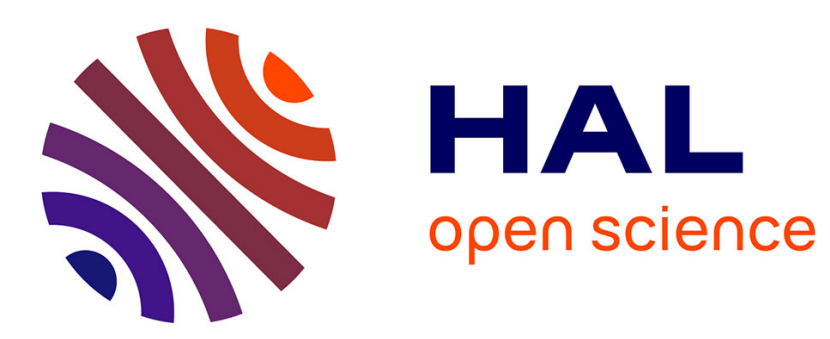

\title{
Germanic Myths and Gender Constructions in German and Dutch Theatre Texts 1660-1780
}

Cornelis Haven

\section{To cite this version:}

Cornelis Haven. Germanic Myths and Gender Constructions in German and Dutch Theatre Texts 1660-1780. Neophilologus, 2010, 95 (2), pp.249-265. 10.1007/s11061-010-9226-0 . hal-00591700

\author{
HAL Id: hal-00591700 \\ https://hal.science/hal-00591700
}

Submitted on 10 May 2011

HAL is a multi-disciplinary open access archive for the deposit and dissemination of scientific research documents, whether they are published or not. The documents may come from teaching and research institutions in France or abroad, or from public or private research centers.
L'archive ouverte pluridisciplinaire HAL, est destinée au dépôt et à la diffusion de documents scientifiques de niveau recherche, publiés ou non, émanant des établissements d'enseignement et de recherche français ou étrangers, des laboratoires publics ou privés. 


\title{
GERMANIC MYTHS AND GENDER CONSTRUCTIONS IN GERMAN AND DUTCH THEATRE TEXTS 1660-1780
}

\section{CORNELIS VAN DER HAVEN}

\begin{abstract}
Germanic liberation myths play an important role in the development of a national consciousness in both the Dutch Republic and the German countries. This article discusses a selection of German and Dutch theatre texts from the seventeenth and eighteenth century about the uprisings and battles of Germanic tribes against the Romans. In existing studies to the Hermannsschlacht-motif in German literature, some scholars conclude that in the course of the eighteenth century male protagonists (especially Arminius/Hermann) were occupying more and more space at the expense of the female characters. By analysing theatre texts on Germanic myths from a long-term international perspective, I will test the correctness of this hypothesis. In the critical reading of key works like Klopstock's bardic drama piece Hermanns Schlacht (1769), I will especially pay attention to the presupposed masculine power fantasies stemming from a more aggressive form of patriotism that was emerging after 1750. Did these fantasies, as they are represented in theatre texts on early national myths, indeed push off female protagonists from the domain of military and political power? What does it mean that these texts were written in a period in which enlightened visions on the fatherland made that the very notion of patriotic heroism was changing radically? How then should we determine the main field of power in these plays, given the fact that male and female characters could use different power instruments in their attempts to act like 'good patriots'?
\end{abstract}

\section{Keywords Hermannschlacht Motive - Batavian Myth - Gender - Patriotism - Theatre}

The liberation myths of the ancient Germanic tribes play an important role in the development of early patriotism in both German and Dutch literature of the $17^{\text {th }}$ and $18^{\text {th }}$ century. The theatre texts I will discuss in this paper are all based on Tacitus' Histories and Annals, which describe the different uprisings of Germanic tribes against the Roman army around the beginning of the Christian era. ${ }^{1}$ National myths in literature proved to be an important means in forging a cultural and moral tie between citizens in two politically as well as culturally fragmented territories: the Dutch Republic and the Holy Roman Empire of the German Nation. The Germanic liberation myths consolidated the image of unity covering the actual disunity of both territories caused by internal political and religious conflicts between the different states and between the princes and regents who ruled them. National myths thus were important in the process of creating a coherent image of the fatherland and of its enemies. Most of these enemy stereotypes date back to the patriotic discourse during the long-lasting wars of the $16^{\text {th }}$ and $17^{\text {th }}$ century: the Eighty Years' War in the Netherlands and the Thirty Years' War in the German countries. Since both wars were to a great extent civil wars amongst fellow-citizens, the narrative of an ancient national struggle

\footnotetext{
C.J. van der Haven

Institute for German and Dutch Philology, Department of Philosophy and Humanities, Freie Universität Berlin, Habelschwerdter Allee 45 - 14195 Berlin

e-mail: haven@zedat.fu-berlin.de

This article was written with financial support of the Alexander von Humboldt-Stiftung.

${ }^{1}$ Langereis (2004) and Flach (1995).
} 
against Rome was important as a source for reflections on a distinct enemy to whom feelings of cultural superiority could be related quite easily.

Literary adaptations of Germanic liberation myths ${ }^{2}$ thus confronted the reader extensively with negative stereotypes of the Romans - such as weakness, servitude, and effeminacy - whereas the Germanic warriors were depicted as strong, proud, independent, and manly. Especially the main protagonists of two important uprisings Hermann (also called Arminius), prince of the Cherusci tribe, and Claudius Civilis, leader of the Batavian tribe could be seen as personifications of that masculine self-image of the patriotic warrior. The use of feminine stereotypes, on the other hand, served to project masculine fantasies of heroic acting in favour of the fatherland; they illustrated the unmanly and cowardly character of the warrior's enemy, as well as the helpless situation of the suffering fatherland. Writing on the Arminius-myth in German literature in the mid-nineties, Hans Peter Herrmann showed that during the second half of the eighteenth century the role of female protagonist, especially of Thusnelda, Hermann's companion, would be progressively marginalised in favour of her masculine counterpart. Whereas in the earlier Hermann-plays women played a modest role in political and military actions, their role in later texts - especially Friedrich Klopstock's Hermanns Schlacht of 1769, to which I will return later - would be reduced to being the domestic support of male protagonists before and after the battle. Herrmann interprets this removal of women from the public domain in the light of masculine power fantasies stemming from a more aggressive form of patriotism that was emerging in the German countries after $1750 .^{3}$

A problematic notion in Herrmann's analysis is the underlying notion of passivity and activity in relation to the role of female protagonists in Klopstock's drama text. Behaving like male protagonists, which means taking part in political and military actions, is interpreted as active and independent; while their acting in other (i.e. private and domestic) domains would imply that women are playing a passive and subordinate role. This narrative of a public-private division in early modern literature and society that separates the genders has been criticised or at least nuanced and complicated in modern gender studies. ${ }^{4}$ The question therefore I would like to raise here is whether this is the right dichotomy to work with for interpreting the heroism of male as well as female protagonists, especially given the fact that this was a period in which enlightened visions on the fatherland made that the very notion of patriotic heroism was changing radically. In a critical response to Hans Peter Herrmann, Elystan Griffiths for instance concludes in relation to the Hermann-play of Schlegel, that especially the participation of female protagonists in war acts should be understood as a by-product of the author's "quasi-democratic" enlightened intentions, whereas the "gender imbalance in battle" in Klopstock's Hermanns Schlacht, who presents military and political power as a privilege of male producers of culture (bards and poets), would be a result of the author's limited understanding of the notion of democratic participation. ${ }^{5}$ Both Griffiths and Herrmann conclude that Klopstock in his play thus sets apart private-domestic forms of patriotic acts from professional-public ones. Female agency then was primarily connected with the first domain, which would make their acting less important and less heroic then that of their male counterparts. But since, especially for the late $18^{\text {th }}$ century, civic emancipation often resulted in efforts to instil civic-private interpretations of patriotism into notions of political and military heroism, a strict separation of gender-roles

\footnotetext{
${ }^{2}$ For an overview of literary texts based on the Arminius and Batavian myths, see Kuehnemund (1966) and Duits (2004) respectively.

${ }^{3}$ Herrmann (1996), 172-173.

${ }^{4}$ See for instance conclusions of recent studies to gender in early modern English society like: Rose (2005), 115116 and Shoemaker (1998), 313-317.

${ }^{5}$ Griffiths (2008), 135.
} 
related to both the public and private domain seems to be less obvious than scholars like Griffiths and Herrmann want to suggest.

\section{The Male Privilege of Political SPEECH}

Since the years between 1740 and 1770 are the heyday of Germanic mythology in German literature, it seems to be obvious that many literary scholars who write about early patriotism focus on that very period. But we should certainly not overlook the long previous history of the reception of Germanic myths in German and Dutch literature, especially during the seventeenth century. As Hans-Martin Blitz, one of Herrmann's students, shows in his dissertation Aus Liebe zum Vaterland (Hamburg 2000), the figure of Arminius or Hermann played already from the early seventeenth century onwards an important role in literary representations of the fatherland. In Lohenstein's novel Arminius und Thusnelda (Leipzig 1689) for instance, the author uses the motive of the raped German princess Walpurgis to describe the violated fatherland and to legitimate the bloodthirsty revenge fantasies of the masculine hero. ${ }^{6}$ Written in the tradition of the French heroic-gallant novel, Lohenstein's novel pays a lot of attention to the character of Thusnelda, Arminius' wife. As we can see at the title page (plate 1), it is a woman (Thusnelda) who very clearly here symbolises the sufferings of the German countries, which are liberated by Arminius and his servants from Roman terror. This image of the suffering woman, often in the role of a raped and wounded virgin, is an image we meet again and again also in Dutch allegorical representations of the defence of the fatherland during and after the Eighty Years' War. The virgin represents the suffering fatherland - the city, the region or the Netherlands as a whole - a fatherland that cannot free itself and needs good patriots to be liberated. With her passive and chaste character, the virgin is of course the ideal object for manly warriors to fight for. Freeing her from the aggression of her oppressors clearly has an erotic connotation, especially since the verb vrijen could mean in Dutch both making love as well as to liberate. ${ }^{7}$

The role of women as the symbolic representation of the suffering fatherland is not necessarily a marginal one. In Joost van den Vondel's play De Batavische Gebroeders (Amsterdam 1662), for example, the long Chorus of Batavian Women dominates the play's first act with extensive lamentations on the sufferings of the country. Speaking in dialogue with the other protagonists, the women express the hope that men will come in action and free them from Roman tyranny. But the two Batavians the women are addressing with their lamentations, the princes Julius and Burgerhart, are not in the position to organise resistance against the dominant Roman army. This masculine powerlessness of the two brothers is presented by Vondel as unnatural and unbatavian, whereas the helplessness of the Batavian women is natural and self-evident. The princes do not recommend the women to resist but to resign themselves to "patient suffering". 8 Because women are thus considered as apolitical characters, their attempts to negotiate with the Romans are interpreted by their Roman oppressors as a trick of men:

Dat schijnt geen vrouwenwerck, maer eer een mans bedrijf.

De man staet achter, en vermomt zich met zijn wijf. ${ }^{9}$

[This seems not to be the work of women, but rather the business of men.

\footnotetext{
${ }^{6}$ Blitz (2000), 82-83.

${ }^{7}$ Meijer Drees (1999), 124-126.

${ }^{8}$ Vondel (1690), 98: "Geduldigh lijden zal u allerminst berouwen."

${ }^{9}$ Vondel (1690), 100.
} 
The man is behind this, and disguises himself with his wife.]

It is Fronto, the Roman centurion, who interprets the lamentations of the Batavian women as manly, because it seems to be aimed at creating resistance. It must have been a "man's head" which stimulated these women to speak out their lamentations in public ${ }^{10}$, and by doing so, making out of emotions a public performative act aimed at changing politics. Women alone, he believes, would not be able to give such a political direction to their vengeful feelings. The Batavian women however defend their position by pointing to the origins of their lamentations, which would stem from natural passions arising from the mother's heart and not from any political intentions. $^{11}$

In the Dutch Arminius-play by Pieter Bernagie (Amsterdam 1686), we meet again Arminius' wife Thusnelda as the personification of the suffering fatherland. Her lamentations cover at least half the play and until the end she remains dependent on the help of the male protagonists to save her from the hands of her jealous admirer Flavius, who kidnapped her by order of the Romans. Inspired by the tragédie amoureuse, and especially the famous French Arminius-plays of Madelaine de Scudéry (Paris 1643) and Jean-Galbert Campistron (Paris 1685) ${ }^{12}$, Bernagie presents the struggle of Arminius in the context of a love intrigue. It is Thusnelda who inspires Arminius with her protestations of love for both him and the fatherland to defend that fatherland against the enemy, while she accuses her admirer Flavius of unpatriotic behaviour, because he supports the Roman occupation of Germany. As a reference to that occupation, Thusnelda's kidnapping has a strong metaphoric dimension. Flavius' betrayal of his original admirer Radwich, because of his love for Thusnelda, likewise has a political counterpart. Flavius is not only a traitor to his admirer but also, together with his father, to the Germanic troops, while secretly cooperating with the Romans. Since the love intrigue thus functions as metaphoric reference to the main plot, it does not really create an independent power structure that might enable Thusnelda to use different moral instruments from the male protagonist. What makes Thusnelda a true patriot in the tragedy of Bernagie is the fact that she is able to suppress her instable female emotions and put in action the male qualities of reason and courage. ${ }^{13}$ She is not vengeful but reasonable, and it is not by using her female qualities but by adopting the male rhetoric of reason that she is able to convince the Roman General Germanicus to set her free.

\section{SUFFERING WOMEN AND FIGHTING MEN}

With the mentioned French Arminius-plays and a couple of Arminius-operas written during the early eighteenth century, Thusnelda became a central figure of theatre texts on the Arminius-myth. ${ }^{14}$ The dramatic kidnapping of Thusnelda must have inspired the Dutch author Joannes le Francq van Berkhey to pay special attention to comparable adventures as experienced by the hero's bride in the Batavian liberation myth. In his play called Claudius Civilis (Amsterdam 1764) Berkhey describes the battle of the Batavian leader against the Romans, around the year 70. Like the other protagonists, the character of Civilia is derived from Tacitus, who

\footnotetext{
${ }^{10}$ Vondel (1690), 115: "Geloof hier heult / Een manshooft me, die 't spel aenschout met koele zinnen, / En broet en koestert het verraet, en houdt zich binnen."

${ }^{11}$ Vondel (1690), 104: "Och ' $t$ is de natuurdrift, diep in 't moeders hart geprent."

${ }^{12}$ Forchert (1975), 49-50 and Kösters (2009), 172-174.

${ }^{13}$ Bernagie (1686), $37 \& 40$.

${ }^{14}$ In 1749 a libretto entitled Thusnelde appeared in Leipzig (text by Johann Adolf Scheibe), implicating that Thusnelda took over the role of main protagonist from Arminius. See Barbon \& Plachta (1995), 281-285.
} 
parenthetically mentions in his Histories the existence of Civilis' bride. ${ }^{15}$ As Berkhey explains in his preface, his decision to highlight the sufferings of Civilia and her son, bringing them in action on the battlefield (as vengeful prisoners of the enemy) was made in order to activate a more natural love for the fatherland on the side of the male protagonist. Civilis' love for his family, his son and wife, makes that he acts like a good patriot, whereas his enemy is the aggressive, heerschzugtige (imperious) Roman governor Cerialis, who is inspired by verwyfde laagheden (womanish turpitudes) - impulsive and sexual passions, as Berkhey explains in the preface to his play. ${ }^{16}$

Although at first sight Civilis' fighting spirit seems to be obvious, static, and unrestricted, the references to his compassion with Civilia and her child are intended to give his readiness to fight a more natural character, but not in the form of bloode verliefdheden (silly love affairs) of the tragédie amoureuse, as the author assures his readers in the preface. ${ }^{17}$ It is Civilia who shows how feelings of revenge and patriotism in the hearts of men could be activated, and how sufferings can be transformed into active resistance. Together with Civilis' sister Jula and her son Bato, who all get kidnapped by the enemy, she thus activates a more natural understanding of the love of the fatherland on the part of the hero. By adding three characters to the Batavian liberation myth who all have family bonds with the hero, Berkhey is able to depict Civilis as a free combatant, whose willingness to fight is not mixed up with the ambition for power, as in the case of Cerialis. True patriots do not go to the battlefield for "gold, crowns, and treasures", but for their Huisgezinnen (families) and the Batavian soil, as Civilis explains to his people after the battle against the Roman army. ${ }^{18}$ The domestic narrative twist therefore makes Civilis' civic patriotism manly, real, and strong; whereas the Romans and their German alleys are depicted as womanly, depraved, and weak.

This femininity (verwyfdheid) and weakness of the depraved enemy also has an ethnic connotation in Berkhey's play. Being interested in anthropological surveys of the history of the Batavian people, Berkhey relates the depraved nature of the Romans' German alleys to their cultural and ethnical relationship with the Roman people. The inhabitants of Cologne, who organised the kidnapping of Civilia and her companions, are unable to show solidarity to the Batavians because the Germanic women of Cologne had married with Roman soldiers, creating a blood relationship between the two ethnical groups. ${ }^{19}$ In his anthropological study to the natural history of Holland (Natuurlijke historie van Holland, Amsterdam 1769-1811), Berkhey qualifies such relationships as disasters of mixed ethnicity (geslagtvermengende rampen). ${ }^{20}$ The chief of Cologne, Agrippinus, thus explains to Civilis in the play that because of the mixed identity of the city's inhabitants, it will be impossible to join the Batavians in a fight against an enemy (the Romans) they really consider as their own people. Civilis in return condemns the slavish soul of the Cologne inhabitants who are disloyal to the Germanic tribes, using a popular Dutch patriotic image, that of the imprisoned lion. ${ }^{21}$ Living in a mixed urban environment, the lion will become tame, denaturalised and domesticated, whereas in the woods and open fields he would recover his natural freedom and willingness to fight. ${ }^{22}$

\footnotetext{
${ }^{15}$ Tacitus (1984), 498-501 (IV, 79).

${ }^{16}$ Francq van Berkhey (1764), fol. *3r/v.

${ }^{17}$ Francq van Berkhey (1764), fol. *3v.

${ }^{18}$ Francq van Berkhey (1764), 46.

${ }^{19}$ Francq van Berkhey (1764), 24-25. See also: Tacitus (1984), 473-475 (IV, 65).

${ }^{20}$ Koolhaas-Grosfeld (2010a) \& (2010b), 91-151.

${ }^{21}$ Meijer Drees (1999), 126-130.

${ }^{22}$ Francq van Berkhey (1764), 23-24.
} 
In Berkhey's tragedy, then, the female protagonist is no longer solely a passive symbol of the suffering fatherland, like in the examples discussed for the seventeenth century. The connection between the suffering of the fatherland and the suffering of the family means that, as the agent of a more natural love for the fatherland, Civilia is an essential character for Berkhey's enlightened interpretation of the Batavian myths. Both in Berkhey's play and in Johann Elias Schlegel's tragedy Hermann (Leipzig 1743), the female heroine's commitment to the struggle of the male protagonists also results in willingness to actively support their husbands during the battle. This appearance of women in the rear of the army also derives from Tacitus' Histories. The presence of children en women during the battle of Vetera/Xanten, was one of the motives in Dutch seventeenthcentury art on the Batavian liberation myth (see plate 2). ${ }^{23}$ But is a mistake, in my opinion, to understand this support of the fatherland by women during military operations as an activation of feminine power, since their inspiration to fight is presented here as an ultimate adaption to and identification with classic masculine heroism. The moral authority and power of women is based on the contrary on their position as political and military outsiders. This position enables them to judge autonomously between true and false patriots. Thusnelda explains in Schlegel's play that good patriots act independently and are inspired by a natural love for both the fatherland and the family, whereas the false hero is

\section{[...] ein fauler Held, den nur die Liebe zieht.}

Den edler Thaten Reiz nicht von sich selbst beweget,

Und der im Schlafe liegt bis ihn ein Blick erreget. ${ }^{24}$

[a lazy Hero, who only is attracted by love

Who is not moved by the impact of noble deeds

And who remains in sleep until he is raised by what his eyes see.]

Female authority here is not based on reasonable political speech, like in Berganie's Arminius-play, but on the reward of the true patriot with love and admiration; whereas the unpatriotic enemy is confronted with aversion and sexual rejection.

While Thusnelda shows her appreciation of Hermann's active and courageous understanding of love for the fatherland by accompanying her man to the battlefield, this instrument of reward is transformed into admiration and total submission incited by the female desire of becoming absorbed in the euphoria of masculine heroism during the fight:

Wie froh will ich mit dir bis zum dem Heere gehn!

Wie froh will ich dich sehn an seiner Spitze stehn!

$\mathrm{O}$ ! daß mich dir dein Sieg zu eigen wiederbrächte,

Nur, daß ich deinen Ruhm auf ewig theilen möchte:

Dein Muth erhüb auch mich, und dein Sieg wär auch mein. ${ }^{25}$

[How happy will I be to come to the army with you!

\footnotetext{
${ }^{23}$ Like the etching in Vaenius (1612) and two sketches for decorations of the Amsterdam city hall by Ferdinand Bol (ca. 1659) and Jurgen Owens (ca. 1662) with the same subject, see Van de Waal (1952), II, plate 78-80. See also Morford (2001), 71 and figure 11.

${ }^{24}$ Schlegel (1963), 149.

${ }^{25}$ Schlegel (1963), 150
} 
How happy will I be to see you in lead of it!

$\mathrm{O}$ ! that I would give you your victory you rightfully deserve,

Just to share in your glory forever:

Your courage would also raise me, and your victory would also be mine.]

Although the intention to fight means here that the heroine aims to become absorbed by masculine heroism, the author uses this image to promote the activation of a träge (slow, lazy) - an adjective Schlegel uses again and again in relation to the German companions of the Roman - fatherland soothed to sleep by a despotic politics. The fatherland should do more then lament about its sufferings and has to actively liberate itself. Patriotism thus is related strongly to the enlightened bellicist discourse of the eighteenth century, in which civic self-defence should not depend on paid armies but on the readiness of all citizens to fight as good patriots. ${ }^{26}$ Yet this enlightened interpretation of patriotism does not lead to a radical change in gender roles; the image of a passive and slow fatherland continuously carries feminine connotations. The lazy fatherland is represented by characters who are unable to choose between Rome and Germany, like Flavius, Hermann's brother. His slow understanding of patriotism is described in Schlegel's tragedy as characterising a weibisch (womanish) fatherland, a fatherland unable to fight and defend itself. Also Claudius Civilis in Berkhey's play taunts the tribes who (like for instance the Gallic tribes) do not want to fight against the Romans as verwyfd (womanish). ${ }^{27}$

The intention of female protagonists to fight, or in any case their fascination with an armed struggle, as Schlegel and Berkhey describe it, should not therefore be understood primarily as an example of crossing the borders of gender-determined behaviour. As a form of female admiration for male military heroism, it still fits into the old hierarchic order of the patriotic community, in which men fight and kill and women care for the wounded soldiers and raise new young patriots. ${ }^{28}$ Many ancient historiographers refer to that role of women on the battlefield, like Tacitus, who characterises the shrieking Germanic women with their wailing babes on the battlefield as "each man's most sacred witnesses and greatest eulogists". ${ }^{29}$ In the plays of Berkhey and Schlegel however, their presence on the battlefield does in the first place have a strong symbolic character, referring to the activation of citizens as armed patriots in general. The plays are not about fighting as such, but about the will to fight, symbolised by the activation of powers that are actually presumed not to use arms. Other characters who were in earlier texts characterised by passive sufferings, are likewise transformed into patriots who want to take up arms and become active in the defence of the fatherland. In Claudius Civilis, Bato, the son of the protagonist, for instance tries to convince his father of his readiness to fight, or at least to observe the fight, and thus become absorbed in his father's courageousness too:

Myn Vader! sta my toe, dat ik met vuurige oogen,

Al kan ik in 't gevegt u nog geen bystand biên,

Ten minsten $u$ van ver mag dapper stryden zien. ${ }^{30}$

[My Father! allow me at least to observe you with fiery eyes,

\footnotetext{
${ }^{26}$ On the relation between patriotism and bellicism during the eighteenth century, see: Leonhard (2008), 181218. On the semantics of German patriotism in the late eighteenth century, see: Fuchs (1991).

${ }^{27}$ Francq van Berkhey (1763), 30.

${ }^{28}$ See also the remarks of Blitz (here in relation to Schönaich's Hermann-epic of 1751) in: Blitz (2000), 128-129.

${ }^{29}$ Tacitus (1999), 80 (7.2). See also Bruder (1973), 128-151 and Amstadt (1994), 81-84.

${ }^{30}$ Francq van Berkhey (1763), 10.
} 
Even though I cannot offer you assistance during the battle,

Let me observe from a distance your courageous fighting.]

Since women are, together with the elderly and children, the classic symbols of the suffering fatherland, their transformation into subjects with an intention to fight, clearly has to inspire the nominal warriors Civilis and Hermann. Mother and child represent a generative and circular concept of love for the fatherland in the tradition of patriotism as the enlightened ideal of good education. They remind the male protagonist of his duty both to fight and to raise new young patriots, educating them in the love for a fatherland which should be served both at home and on the battlefield.

\section{PATRIOTIC INSPIRATION AND POLITICAL POWER}

The transformation of women as suffering objects for which manly warriors risk their life into characters with an own intention to fight can be observed more strongly in the Claudius Civilis-play written by Willem Haverkorn in $1779 .{ }^{31}$ The main male hero here is not Civilis but Brinio, leader of the Germanic tribe of the Cananefates, who admires Civilis' courageous niece Adelheide. Adelheide's second admirer is her old boyfriend Briganticus, the unstable and irresolute Batavian, who serves the Roman army. On the one hand, Brinio describes how the fatherland suffers from Roman tyranny, using the image of the elderly and women who are incompetent to use arms and to defend themselves against the Romans. ${ }^{32}$ On the other hand, he mentions the heroine Adelheide, who, together with a battalion of armed Batavian women, attacked the false patriots under Briganticus. ${ }^{33}$ The courageous women created such a confusion and respect with their armed attack that Briganticus decided to fly from the battlefield, together with the rest of the army. With her courageous behaviour, Adelheide represents the subject who by nature is incompetent to take up arms, but disposes of such an incredibly strong patriotic nature, that she nevertheless takes them up to confront the enemy. Here, the heroine not only dissolves in her adoration for manly warriors by accompanying them in battle, like Thusnelda in Schlegel's Hermann-tragedy, but consciously crosses the natural borders of her supposed feminine passivity, transforming her initial weakness into an instrument of patriotic strength. In doing so, she represents the strength that patriotism can exert on its subjects. Her courage implicitly accuses the weak and degenerated male patriots who do not even dare to defend themselves and who decide to fly from the battlefield.

Haverkorn's tragedy shows how the love for the fatherland, as a patriotic passion defended by reasonable, virtuous, and manly warriors, can be so strong, that the patriotic subject crosses the borders of nature. In Klopstock's play Hermanns Schlacht. Ein Bardiet für die Schaubühne (Hamburg/Bremen 1769), the first part of his trilogy on the life of Hermann the Cherusker ${ }^{34}$, reason becomes replaced by a form of patriotic motivation which depends more and more on inspiration and enthusiasm. The tragedy does not concentrate on the Schlacht, the battle itself, but on the origins of patriotic passions. The real heroes in this play, which is called a Bardiet, a song of bards, are not the fighters but the ancient Germanic bards, presented by Klopstock as an ancient caste of poets and singers who inspire the fighting Germans with their performances of songs and rituals.

\footnotetext{
${ }^{31}$ On the reception of the play, see Teitler (1998), 62-63. Summary of the play in: De Leeuwe (2003), 28-30.

${ }^{32}$ Haverkorn (1779), 3: "Wyl ze onbekwaam zyn tot het voeren van 't geweer."

${ }^{33}$ Haverkorn (1779), 5-6.

${ }^{34}$ The other two plays of the trilogy are: Hermann und die Fürsten (Hamburg 1784) and Hermanns Tod (Hamburg 1787)
} 
The bards are standing at the top of a cliff, whereas the Germanic soldiers remain invisible characters during the battle at the feet of that cliff. By focusing on the power poetry can exert on military acts, Klopstock has Hermann and his fellow-fighters share their heroism with the bards and druids, which is explained to the bards by Hermann's aged father, who states that not only his son's weapons, but also the songs of the bards are a crucial factor in deciding the fight ("Eure Gesänge stärken des Streitenden Arm.") 35

The image of a loving and caring woman is an important source of inspiration for the fighting men in Klopstock's Bardiet. The first bardic song is about mothers and brides who are nursing the soldiers' wounds, an image inspired by some remarks in Tacitus' Germania. ${ }^{36}$ This song, which praises the women who lick the blood from the wounds of Germanic warriors ${ }^{37}$, certainly has maternal as well as sexual connotations. Bleeding rather than fighting is the keyword of the play in referring to the patriotic quality of men who do not shun sufferings and self-sacrifice. Only by showing their readiness to bleed can men be good patriots. Segest for instance, the companion of the Romans, is only allowed to fight together with the Germans after showing his readiness to shed his own blood, stating that "Spätes Blut ist auch Blut" (also late blood is blood). ${ }^{38}$ It is not Hermann or Siegmar, but Brenno, the chief bard, who decides after this confession that Segest is allowed to fight, but not after he has listened to their songs that will inflame the spirit of war in his heart. An important difference with the idea of patriotic motivation in the earlier tragedies is that this need for inspiration of the indecisive warrior is no longer presented as a weakness. On the contrary, Segest's change of attitude is presented as a positive example and even his Trägheit is not a problem, since every patriot has his doubts and has to overcome these doubts by patriotic inspiration before joining the battlefield.

As Elystan Griffiths states in his article on the Hermannschlacht-motive in German literature, women are presented in the songs of the bards as helpless characters in need of male protection. ${ }^{39}$ But it is important to conclude also that in other songs, Thusnelda and her mother Bercennis are presented as fellow-combatants during the battle inspired by the image of the tender and warlike Diana, the goddess of the hunt. ${ }^{40}$ However, this is not what empowers the female protagonists in the play. While in the tragedies of Schlegel and Berkhey women do in the end adopt the masculine rhetoric of patriotism or indeed take part in the fighting itself (Haverkorn), in Klopstock's play women and bards own instruments of their own to support the fatherland: the instrument of inspiration. The source of inspiration is patriotic speech itself, which can be so powerful that it can transform slow patriots as well as elderly and children into active and vital combatants. This transformation is described as a kind of ecstasy caused directly by the patriotic songs. One of the Opferknaben (young assistants of the druids during the sacrifices) for instance cannot hold himself back from the battlefield because of the great appeal of the songs. ${ }^{41}$ The boy's father praises his wife for having born such a proud young patriot and thanks Wodan for calling his son to the battlefield. The child indeed goes to the battlefield, fights and returns to the rock of the bards deadly wounded.

\footnotetext{
${ }^{35}$ Klopstock (1769), 18. On the relation between the bardic songs and the political intentions of the author, see: Zimmermann (1987), $250 \mathrm{ff}$.

${ }^{36}$ Tacitus (1999), 80 (7.2): "to their mothers and wives they take their wounds, and the women are not afraid to count and examine the blows; they bring to the warriors both food and exhortations."

${ }^{37}$ Klopstock (1769), 12.

${ }^{38}$ Klopstock (1769), 48.

${ }^{39}$ Griffiths (2008), 128-129.

${ }^{40}$ Klopstock (1769), 25, 112-113.

${ }^{41}$ Klopstock (1769), 62-65.
} 
Unlike the elderly and children, women are not to be seen on the battlefield in the play of Klopstock. At first sight, the author realises a clear separation between gender roles in correlation to the public and private domain, reducing the role of Thusnelda and other women to that of taking care for the soldiers: whetting their spears, nursing their wounds, decorating their shields, and cooking their meals. Nevertheless, we should hesitate to consider the Bardiet solely as manifesting the marginalisation of women within patriotic discourse. Central to Klopstock's play is an enlightened holistic interpretation of the fatherland in which all citizens should become active and understand their own duties as good patriots. A civic discourse on war and fatherland had to be explored before the domains of private and public life could be described both separately and in relation to each other. Although, in the case of Klopstock, the distinction of roles leads to a reduction of female power in the military field and to the fact that women lose their capacity of interfering directly in the political and military domain, they do become more important in the new domain of patriotic inspiration, a domain to which military agency as such has become subordinated

Although Klopstock was a critic of offensive war politics, his Hermann-play clearly can be read as propagating an aggressive non-rational discourse on patriotism in which revenge towards the foreign enemy is represented as a justified motivation for war. ${ }^{42}$ While in the earlier tragedies discussed here feminine heroines try to present themselves as non-vengeful, mirroring manly patriotic reason, Klopstock presents their revenge in the end as a positive emotion, because it can activate a more warlike form of patriotism in the hearts of men. This creates a new power structure, in which especially women are playing a crucial role, as in the case of Hermann's mother who pleads to avenge their people, even after the battle against the Romans has come to an end. She asks her son to kill especially those Romans

Die unsre Knaben erwürgt, die unsre Jungfrauen gezwungen haben, gegen ihr eignes Leben zu wüten, die Ihn getödtet haben! Die sollen nicht um seine Leiche her in dem Dampfe des Todtenfeuers liegen? ${ }^{43}$ [Who strangled our boys, who forced our maids to rage against their own lives, who killed them! Should they not just lie here around his dead body in the fumes of death fires?]

Though the argumentative structure of these lamentations shows some resemblance to the Chorus of Batavian Women in Vondel's tragedy, the effect of these lamentations on the hero is very different. The call for revenge cannot be neglected, nor can it be suppressed by reason anymore, and Hermann therefore has to capitulate to his mother's aggressive patriotism. Hermann initially rebukes his mother for her vengeful feelings, meanwhile trying to control his own feelings of revenge both by reason and by showing his compassion with the enemies, but in the end he is not able to neglect her rhetoric of aggressive revenge. Remaining silent for some moments after her vengeful outburst, Hermann is persuaded by the emotions of his mother, and looking at the dead body of his father, he swears to kill the new legions of Roman soldiers expected to arrive soon. Vengeful patriotism which defeats political reason thus is especially remembered, advocated, and activated by the formerly passive forces: women and the elderly. These forces cause the male hero to dispel the discourse on fatherland and patriotism that is solely based on reason, as is illustrated by the outburst of revenge on the part of the hero:

\footnotetext{
${ }^{42}$ See also the remarks of Von Essen (1998), 102-126.

${ }^{43}$ Klopstock (1769), 133.
} 
... Du sollst gerochen werden, mein Vater! ... ja du sollst gerochen an den neuen Legionen werden! an allen ihren Tribunen! und Legaten! und Feldherrn! .... Ha, an ihren Tribunen gerochen mit Todesrache! ${ }^{4 . .}{ }^{44}$

[... You will be avenged, my Father! ... yes you will be avenged on the new legions! and on all their tribunes! and legates! and generals! ... Hah, on their tribunes avenged with the vengeance of death!]

This emphatic form of patriotism culminating in patriotic vengeful ecstasy on the part of male warriors who are inspired by the songs of bards and the image of fighting and caring women is absent from the Dutch plays I discussed earlier. Although Berkhey and Haverkorn certainly had political intentions with writing their tragedies, at least in relation to early bellicism and the civic re-appropriation of discourse on war and fatherland in general, they did not succeed in transforming the discourse on patriotism as such. Standing in the long tradition of Dutch neo-classicism, the literary style of both Berkhey and Haverkorn remains stiff and distant, which seems to preclude a more emphatic patriotic rhetoric. Not only is the representation of the Batavian women restricted to their role of merging into the manly heroism of the old Batavian liberation myth, but patriotic inspiration also remains an abstract phenomenon, motivating the heroic patriot's acts but yet an invisible force for the reader or spectator. Neither author was able to write a tragedy which highlighted patriotic enthusiasm and inspiration itself. Even while defending revolutionary political concepts, the patriotic discourse in Dutch literature of around 1770 still was a conservative one, falling back on the idea of political and cultural crisis and decline and on the necessity to restore the fatherland to its former glory. ${ }^{45}$ A majority of the Dutch revolutionary Batavian patriots began to see quite lately that it would be necessary to develop a more visionary political concept for the reorganisation of the Dutch Republic and to find a new political, cultural, and literary language to revitalise the Dutch discourse on patriotism.

Klopstock, however, did succeed in constituting a play which took shape in a performative (theatrical) speech-act on stage, praising an imaginative German nation by foregrounding the origins of patriotic discourse itself. With his Hermann-play Klopstock stages a competing discourse to the older national discourses based on the idea of a German nation, like the early modern Reichspatriotismus. Although he chose to dedicate his Bardiet to the emperor Joseph II, Klopstock knew very well that it would not be the old political construction of the German Empire which could realise his patriotic ideals. Klopstock believed in the importance of culture and science in the process of political modernisation. The ancient songs of the bards in Klopstock's play could be seen as representing such a pre-modern state of the cultural constructed by the cotemporaneous bards, i.e. Klopstock and the circle of German writers and intellectuals defending the idea of German literature as originating patriotic inspiration and enthusiasm.

But Klopstock's Hermanns Schlacht is more then a defence of German cultural patriotism, it is, as Hans Peter Herrmann rightly states in his article, a self-constitution of masculinity and especially of the right of male warriors to defend the country and kill the enemy. ${ }^{46}$ In this discursive space of patriotism, the role of women indeed is reduced to an object of masculine possession, constituting a justification to fight and kill. Still, we should not stick to that single observation, underestimating the symbolical value of the activation of women as a source of inspiration for male patriots, without relating their role to that of the singing bards. Although one could

\footnotetext{
${ }^{44}$ Klopstock (1769), 135.

${ }^{45}$ Kloek \& Mijnhardt (2001), 215-217.

${ }^{46}$ Herrmann (1996), 172.
} 
say that in Klopstock's play the role of women is reduced once again to that of the seventeenth-century wailing woman, we must bear in mind that these lamentations are now transformed into emphatic songs, activating patriotic pleas for revenge. Both to constitute Hermann and the other Germanic warriors as free patriotic combatants and to legitimate a more emphatic aggressive patriotism, it was necessary to stage independent women and bards as the vengeful commentators of a patriotic war providing the nominal fighters with the inspiration they need. This way of staging inspired patriotism is blocked in the plays by Berkhey and Haverkorn, where the direct participation of women in the armed battle against the Romans does not create an emphatic intensification of patriotic discourse, because it results in submitting femininity to classic forms of masculine heroism. Klopstock literally pushes women back to the side-line of the battlefield, representing them as the uninvolved commentators on the battle. But it is by reducing their role to that of inspiring spectators, that he draws them towards the centre of a patriotic discourse which is not interested in highlighting fighting as such but in the will to fight as well as the inspiration needed to let male warriors kill and bleed for the fatherland as free patriots.

\section{REFERENCES}

Amstadt, J. (1994). Die Frau bei den Germanen. Matriarchale Spuren in einer patriarchalen Gesellschaft. Stuttgart, Berlin, Köln: Kohlhammer.

Barbon, P. \& Plachta, B. (1995). Arminius auf der Opernbühne des 18. Jahrhunderts. In R. Wiegels \& W. Woesler (Eds.), Arminius und die Varusschlacht. Geschichte-Mythos - Literatur (pp. 265-290).

Paderborn, München, Wien, Zürich: Ferdinand Schöning.

Bernagie, P. (1686). Arminius, Beschermer der Duytsche Vryheid. Amsterdam: Albert Magnus.

Blitz, H-M. (2000). Aus Liebe zum Vaterland. Die deutsche Nation im 18. Jahrhundert. Hamburg: Hamburger Edition.

Bruder, R. (1973). Die germanische Frau im Lichte der Runeninschriften und der antiken Historiographie. Berlin, New York: De Gruyter.

Duits, H. (2004). Tussen Bato en Burgerhart. Bataven en Bataafs verleden in de Nederlandse letterkunde van de Gouden Eeuw. In L. Swinkels (Ed.), De Bataven: verhalen van een verdwenen volk (pp. 196-213). Amsterdam: De Bataafsche Leeuw.

Essen, G. von (1998). Hermannsschlachten. Germanen- und Römerbilder in der LIteratur des 18. und 19.

Jahrhunderts. Göttingen: Wallstein Verlag.

Flach, D. (1995). Der taciteische Zugang zu der Welt der Germanen. In R. Wiegels \& W. Woesler (Eds.), Arminius und die Varusschlacht. Geschichte - Mythos - Literatur (pp. 143-166). Paderborn, München, Wien, Zürich: Ferdinand Schöning.

Forchert, A. (1975). Arminius auf der Opernbühne. In G. Engelbert (Ed.), Ein Jahrhundert Hermannsdenkmal 1875-1975 (pp. 43-57). Detmold: Natürwissenschaftlicher und Historischer Verein für das Land Lippe. Francq van Berkhey, J. le (1764). Claudius Civilis, Hersteller der Bataafsche Vryheid. Amsterdam: Yntema en Tieboel.

Fuchs, P. (1991). Vaterland, Patriotismus und Moral. Zur Semantik gesellschaftlicher Einheit. Zeitschrift für Soziologie 20-2, 89-103. 
Griffiths, E. (2008). Hermanns Schlachten: Gender, Culture and the German Nation in the Long Eighteenth Century. German Life and Letters, 61, 118-136.

Haverkorn, W. (1779). Claudius Civilis; Treurspel. Amsterdam: Izaak Duim.

Herrmann, H.P. (1996). Arminius und die Erfindung der Männlichkeit im 18. Jahrhundert. In H.P. Herrmann, H-

M. Blitz \& S. Moßmann (Eds.), Machtphantasie Deutschland: Nationalismus, Männlichkeit und Fremdenhaß im Vaterlandsdiskurs des 18. Jahrhunderts (pp. 161-191). Frankfurt a.M.: Suhrkamp.

Kloek, JJ. \& Mijnhardt, W. (2001). 1800. Blauwdrukken voor een samenleving. Den Haag: Sdu Uitgevers. Klopstock, F.G. (1769). Hermanns Schlacht. Ein Bardiet für die Schaubühne. Hamburg/Bremen: Johann Henrich Cramer.

Kösters, K. (2009). Freiheit der Germanen. Eine französische Karriere. In R. Aßkamp (Ed.), 2000 Jahre Varusschlacht - Mythos (pp. 172-186). Stuttgart: Konrad Theiss Verlag.

Koolhaas-Grosfeld, E. (2010a). De ontdekking van de Nederlander in boeken en prenten rond 1800. Zupthen: Walburg Pers.

Koolhaas-Grosfeld, E. (2010b). Sekse in de Natuurlijke Historie. In M. Everard \& M. Aerts (Eds.), Kunne. Een begripsgeschiedenis van sekse in Nederland, Amsterdam: AUP (forthcoming).

Kuehnemund, R. (1966). Arminius ort he Rise of a National Symbol in Literature. New York: AMS Press.

Langereis, S. (2004). Van botte boeren tot beschaafde burgers. Oudheidkundige beelden van de Bataven, 15001800. In L. Swinkels (Ed.), De Bataven: verhalen van een verdwenen volk (pp. 71-105). Amsterdam: De Bataafsche Leeuw.

Leeuwe, H. de (2003). De Amsterdamse Schouwburg in 1795: het eerste jaar der Bataafse vrijheid. Zutphen: Walburg Pers.

Leonhard, Jörn (2008). Bellizismus und Nation. Kriegsdeutung und Nationsbestimmung in Europa und den Vereinigten Staaten 1750-1914. München: R. Oldenbourg Verlag.

Meijer Drees, M. (1999). Vechten voor het vaderland in de literatuur, 1650-1750. In N.C.F. van Sas (Ed.), Vaderland. Een geschiedenis vanaf de vijftiende eeuw tot 1940 (pp. 109-142). Amsterdam: AUP.

Morford, M. (2001). Theatrum Hodiernae Vitae. Lipsius, Vaenius and the Rebellion of Civilis. In K. Enenkel, J.L. de Jong \& J. de Landtsheer (Eds.), Recreating Ancient History. Episodes from the Greek and Roman Past in the Arts and Literature of the Early Modern Period. Leiden, Boston, Köln: Brill.

Rose, M.B. (2005). Gender and Heroism in Early Modern English Literature. Chicago, London: University of Chicago Press.

Schlegel, J.E. (1963). Hermann, Ein Trauerspiel. In W. Schubert (Ed.), Johann Elias Schlegel. Ausgewählte Werke (pp. 124-171). Weimar: Arion Verlag.

Shoemaker, R.B. (1998). Gender in English Society 1650-1850. The Emergence of Seperate Spheres? Harlow (etc.): Longman.

Tacitus (1984). J. Borst (Ed.), Historiae/Historien. München/Zürich: Artemis Verlag.

Tacitus (1999). J.B. Rives (Ed.), Germania. Oxford: Clarendon Press.

Teitler, H. (1998). De opstand der 'Batavieren'. Hilversum: Verloren.

Vaenius, O. (1612). Batavorum cum Romanis Bellum, à Corn. Tacito lib. IV \& V. Hist. olim descriptum, figures nunc aneis expreßum. Antwerp: the Author. 
Vondel, J. van den (1690). Batavische Gebroeders of Onderdrukte Vrijheit. In Alle de treur-spelen van de heer J.V. Vondel in twe deelen, zo als dezelve vervolgens in 't licht zyn gegeven (pp. 87-169). Amsterdam: Joannes de Wees.

Waal, H. van de (1952). Vaderlandsche geschied-uitbeelding 1500-1800. Een iconologische studie. Den Haag: Martinius Nijhoff.

Zimmermann, H. (1987). Freiheit und Geschichte. F.G. Klopstock als historischer Dichter und Denker. Heildelberg: Carl Winter. 